\title{
RECEPTIVENESS TO FLEXIBLE EMPLOYMENT AT HUNGARIAN
}

\section{SMEs}

\section{A RUGALMAS FOGLALKOZTATÁS IRÁNTI FOGADÓKÉSZSÉG A MAGYAR KKV-K KÖRÉBEN}

\author{
Ákos ESSŐSYa ${ }^{\mathrm{a}}$ Tamás VINKÓCZI ${ }^{\mathrm{a}}$ \\ ${ }^{a}$ PhD student Széchenyi István University, Doctoral School for Regional Economic Sciences, 9026 \\ Győr, Egyetem tér 1., akos.essosy@mapi.hu; vinkoczi.tamas@sze.hu;
}

Cite this article: Essősy, Á., Vinkóczi, T. (2018). Receptiveness to Flexible Employment at Hungarian SMEs. Deturope, 10(1), 116-130.

\begin{abstract}
Nowadays, only companies that are adaptable and flexible in their structure and processes can survive. The basis for a motivated company aiming for peak performance is organisational innovation. Hungary is one of the less innovative countries in Europe. Only organisations that can integrate new solutions smoothly into their everyday operations will remain truly competitive. The Government of Hungary, in its Partnership Agreement with the European Union, set out the goals for improving and supporting the adaptability of enterprises, the promotion of flexible and family-friendly workplace practices and services, and the employment of women with young children. The aim of this study is to demonstrate, through a Hungarian example, the receptiveness of Hungarian small and medium-sized enterprises to flexible forms of employment. The effect of flexible employment on economic adaptability and competitiveness through workforce efficiency and retention is examined. Its aim is the raise the awareness of options to increase employment among Hungarian SME managers.
\end{abstract}

Keywords: flexible employment, economic competitiveness, small and medium-sized enterprises, partnership agreement, Hungary

\begin{abstract}
Absztrakt
Ma csak azok maradnak talpon, akik képesek a változásra, rugalmasan alakítják a cégstruktúrát, folyamataikat. A motivált, csúcsteljesítményre törő cég alapja a szervezeti innováció. Ma Magyarország a mérsékelt innovátor országok közé tartozik Európában. Az új helyzetekhez alkalmazkodó szervezet, amelyik az új megoldásokat rugalmasan beépíti a mindennapi müködésébe, tud csak igazán versenyképes maradni. Magyarország kormánya az Európai Unióval kötött Partnerségi Megállapodásban célul tủzte ki a vállalkozások alkalmazkodóképességének fejlesztését, segítését, a rugalmas és családbarát munkahelyi gyakorlatok és szolgáltatások elterjesztését, valamint a kisgyermeket nevelő nők foglalkoztatását. Jelen tanulmány célja egy magyar példán keresztül bemutatni, hogy a rugalmas foglalkoztatásra milyen fogadókészség van Magyarországon a kis és középvállalkozások körében. Vizsgálat tárgyát képezi, hogy a rugalmas foglalkoztatás növeli e a gazdasági alkalmazkodóképességet és versenyképességet a munkaerö hatékonyságán és megtartásán keresztül. Mindezt azzal a céllal teszi, hogy felhívja a magyarországi KKV-k vezetőinek figyelmét a foglalkoztatás bővítésének lehetőségeire.
\end{abstract}

Kulcsszavak: rugalmas foglakoztatás, gazdasági versenyképesség, kis és középvállalkozások, partnerségi megállapodás, Magyarország

\section{INTRODUCTION}

One of the most important targets of the Europe 2020 strategy (European Committee, 2010) is increasing the quantity and quality of jobs. This ten-year strategy prioritising employment and 
intelligent, sustainable, and inclusive growth was the first to define key goals. The first main goal is increasing the employment rate in the $20-64$ age bracket to $75 \%$ by 2020 . In the field of integration and the fight against poverty, lifting at least 20 million people out of poverty and social exclusion is a further goal. An additional goal is to improve the quality and performance of education and training systems, reduce the share of early school leavers to $10 \%$ from the current $15 \%$, and increase the share of the population aged 30-34 having completed higher or comparative education from $31 \%$ to at least $40 \%$. Member States must interpret all key goals into national goals, taking into consideration their initial and national circumstances.

The Government of Hungary, in its Partnership Agreement with the European Union (Hungarian Ministry of National Economy, 2014) - in accordance with the discussed strategy - set out the goals for improving and supporting the adaptability of enterprises, the promotion of flexible and family-friendly workplace practices and services, and the employment of women with young children. We presume that a number of groups on the job market cannot or are not willing to take up a traditional form of employment because they are raising a child, caring for an elderly relative, or participating in education. In order to exploit their potential, the aim of the development concept is to improve the enterprise work organisation culture, promote flexible work arrangements, and balance work and private life.

Flexible employment forms are gaining in popularity in Hungary, and there is increasing research into their various fields, but so far, there is little solid, scientifically-based experience and few findings with a comprehensive perspective on the range of companies in question.

The effect of flexible employment on economic adaptability and thus competitiveness, primarily through workforce efficiency and retention, is expected on the enterprise side.

A number of flexible forms of employment are available in Hungary, the most significant ones being: simplified or casual employment, part-time employment, job sharing, flexible working hours, teleworking, home office, outworking, temporary employment, employment by multiple employers.

Flexible forms of employment support employees in creating a work-family balance, thus making their workplace more attractive. Family-friendly operation is also a key element in reinforcing employer reputation and social responsibility. From the employee's point of view, a flexible workplace is more attractive, thus it is synonymous with finding valuable workers faster, and being more successful in keeping them.

The opportunities for increasing employment involve different needs on the employer's and on the employee's side. In this study, I will demonstrate receptiveness to flexible employment in the Hungarian SME sector by means of a specific example. 


\section{Topic Justification}

"The tendency of development is undoubtedly that what, in the past, had been-regardless of any traditional differences - considered the norm as regards the employment relationship and working hours became an exception, and what had been considered an exception is now what defines the current reality (Voss, 1997).

Labour market mobility is a business goal focused on faster, more successful, and more effective responses to changing environmental requirements, compared with traditional employment models. This can be achieved using methods known as flexible employment practices or atypical forms of employment.

According to Frey (2001), "Employment that is generally considered standard or regular keeps losing ground. Traditional, 'normal' employment means full-time employment with a permanent contract, in employee status, with working hours usually equally distributed over five working days, usually from Monday to Friday, working regular, usually daytime, hours. Whatever is different is atypical, irregular, flexible". This is not an external constraint to force on job market participants, but an opportunity to increase competitiveness that should not only be considered, but used as a basis in order to solve problems such as falling unemployment, increasing the number of employed people, or, on the company side, handling changes in consumer needs.

The economic and flexible utilisation of the workforce is also a company need, as it affects competitiveness and has a significant effect on workforce-related costs, that are especially important in the strongest national economy sector, the service sector, as it normally generates the largest costs. (Finna, 2008)

By driving work flexibility and work quality, flexible forms of employment may be used to free potential "reserves" on both the supply and demand sides, which can lead to an increase in the number of people employed. Solutions allowing the balancing of work and private life allow the successful return to the job market of people who would otherwise be excluded, especially the parents of young, as well as the improvement of their adaptability. Measures that promote employment contribute to increased employment of parents of young children and other groups in special situations (e.g. people who both work and study, those caring for old or sick family members). One of the most important methods of increasing employment is flexible employment. In Hungary, even though there are broad legal possibilities for its use, the rate of flexible employment is low.

According to Hungarian Central Statistical Office data (Hungarian Central Statistical Office, 2015), the number of flexibly employed people in the 15-64 age group rose by almost 80,000 between 2008 and 2015, to approximately 250,000. Fixed-term employment is the most popular form (approximately 1 in 10 employees have such a contract today). It indicates 
the growth in the role of flexible forms of employment (fixed-term contracts, part-time, teleworking, temporary employment, self-employment). But we still have a long way to go compared to other countries: according to 2015 Central Statistical Office data, while in the 20-64 age group in Holland, 27.8 percent are employed part-time, Hungary's 5.7 percent rate is one of the lowest in the EU (Hungarian Central Statistical Office, 2015).

According to Poór (2014) the flexible employment forms are not popular in the following countries: Hungary, Poland, Czech Republik and Slovakia yet. The reason why the flexible employment formats have not been widely recognised in those countries is, that these employment formats and their advantages/disadvantages are not acknowledged yet.

Companies aim for fewer obligations and for unbinding employees from the company (Szabó and Négyessi, 2004). Competitiveness is the ability of an organisation (person) to recognise the possibilities and risks of changing conditions and take the chance to change the circumstances in order to realise its own goals and interests. An organisation can react quickly to the recognised need for change if it can be flexible in regard to its resources. Along with other resources, the availability of enough high-quality employees, as one of the basic production factors, is of paramount importance. The past decades' research into human capital has proven that creating financial and technical tools that match others' similar tools is much easier (and often quicker) than the creation of human capital serving excellence, innovation, and adaptation.

A systematic review of Hungarian empirical results highlights a number of empirical results and research hypotheses that may serve as a useful starting point for upcoming research:

1st) This review is made more difficult by the fact that not everything that seems to be flexible employment actually is that, and flexible employment is often not visible to statistics. A number of studies point out that a portion of employees officially in flexible statuses actually work full-time, and are put in such a status for taxation and contributions considerations, and a significant proportion of fixed-term contracts conceal regular employment in reality. At the same time, a significant percentage of undeclared employed people work in essentially flexible forms, but they do not appear in official statistics (e.g. Köllö, 2012; Finna, 2008; Asztalos et al., 2011; Hovánszki, 2005).

2nd) As for the awareness of flexible forms of employment, Hungarian companies are faring better than in regard to how widespread these practices are: According to expert interviews conducted by Hárs (2013), companies are conscious of the more common forms, and are only unsure about the newer, more innovative solutions (e.g. job sharing), which was confirmed by the questionnaire survey in both this and the other recent research. 
3rd) It is especially characteristic of SMEs that they knew the form itself, but not the content and depth of the concept, therefore decisions were based on intuition, as well as previous ideas and experiences (Finna, 2008; Asztalos et al., 2011).

4th) According to Finna's (2008) research, the switch to flexible employment is not an easy task, especially for SMEs. Initially, companies try to resolve tasks requiring higher flexibility with the following tools:

- reorganising full-time employees,

- involving subcontractors and outsourcing activities

5th) Negative attitudes to and rejection of flexible employment typically characterise Hungarian-owned smaller (micro and small) enterprises (Hárs, 2013).

6th) Employees are rather distrusting of flexible employment. They perceive a serious risk in the flexibly employed people possibly becoming marginalised and their status and position being less secure compared to the 'core' of the full-time employees. They undertake it voluntarily if flexible employment is the form of employment that suits their life situation.

It is important to point out that the increase in the prevalence of various atypical forms of employment is not synonymous with a decrease in typical, 'normal' employment, but, focusing on a niche, it creates new jobs where traditional, full-time, permanent contracts are not an option for financial reasons.

\section{A practical example of promoting flexible employment}

A general goal of the Partnership Agreement is the increase in sustainable growth and high added value production and employment, which is the subject of five of the Government's National Priorities. The goals are the following:

- Improving the competitiveness of economy participants and increasing their international activity.

- Improving employment by driving economic growth and social inclusion.

- Improving energy- and resource-efficiency.

- Handling social inclusion and population challenges.

- Implementation of local and regional developments aiding economic growth.

9 operative programmes aid the realisation of the goals and the execution of the Partnership Agreement. The one with the highest ratio of funds is the Economic Development and Innovation Operational Programme (GINOP). The GINOP programme encompasses 8 funding priorities. The fifth priority, 'Employment', supports increased employment by improving workforce supply and by incentivising the employment of non-employed people, thus completing the logic of the other priorities for improving workforce demand and competitiveness. The planned measures primarily target improving the employability of those 
who may be employed on the primary labour market and increasing the adaptability of employers and employees utilising a complex toolkit.

In the 'Employment' priority, GINOP-5.3.1-14 'Promotion of flexible employment in convergence regions' programme was published in 2014 as part of the 'Széchényi 2020 programme'.

The programme is implemented in a two-round process. In the first round (component A), the aim of the process is to choose providers offering flexible/family-friendly screening, that during execution, will perform screening of businesses for free during execution, and prepare a re-organisation plan and track the realisation of these plans in order to increase flexible employment.

In the second round, (component B), the screened businesses may, based on the reorganisation plan, request funding for the organisational, human resources, and other measures that aid flexible employment.

Thus, in the first round of the programme, professional providers were selected that would later perform the organisational screening of the joining SMEs for free due to the grant funding. 11 organisation development consortia or organisations with experience in introducing flexible employment won a total of HUF 2.007 billion in European Union funding. One of the first tasks of the providers was the creation of a shared and unified, highquality professional methodology along with an implementation plan that ensured the nationwide equal accessibility of the services for the SME sector (with the exception of the Central Hungary region).

In the second round, the screened employers could draw funds to cover the costs of the recommended organisation development. Therefore, only companies that had undertaken screening in the GINOP 5.3.1 part of the programme with the selected providers could take part in the second round. The selected professional consulting companies reached almost 27,000 SME employees in their analytical, evaluation, and development activities. They started their analytical work between July and October 2015 in close cooperation, with coordination by the consortium of IKFA Iparfejlesztési Közhasznú Nonprofit Kft. The further two expert members of the lead consortium were the KONTAKT Foundation and MAPI Magyar Fejlesztési Iroda Zrt. (MAPI). As a human resources and organizational development expert at MAPI, I actively participated in the three-month professional work, during the course of which the unified professional methodology and the implementation plan used by the providers in the screening of the SMEs was created. Following the screening, preparations for the introduction of flexible work are still being made at the companies concerned.

The research and the analysis of data and results is still ongoing with more than 800 companies involved, it is a continuous research which study is planned to be finalized in May 
2018. At those companies who are open for the flexible employment formats, the process of introducing different types of flexible work has started.

\section{OBJECTIVES AND METHODS}

This study explores the opportunities of the organisational utilisation of labour market flexibility and its actual utilisation. The aim of the study is to gather information on small and medium-sized enterprises' need for and use of flexible forms of employment in Hungary. According to my previous hypothesis, the opportunities for flexible employment that could have a significant effect upon competitiveness especially for SMEs are far from being completely utilised. In my research, I primarily explore the employer's side, as in my experience, management decisions have a fundamental effect on the organisational implementation and operations of flexible forms of work. I believe that the creation and existence of atypical work has an effect on the organisation, its flexibility, and its efforts to achieve further flexibility.

In the consortium's work as a whole, data collection was performed at 828 companies. More than 15,000 management and employer questionnaires were recorded by the experts working in the consortium at the companies that had applied to take part in the programme.

There are two major groups of research methods: primary and secondary research. Primary research is the first-hand collection and evaluation of data not known to others in one's own research, while secondary research is the analysis of data obtained and published by others. In this study, both methods are used simultaneously.

As primary research, I performed a questionnaire-based survey, and personally interviewed company managers. The database I have gained from these interviews (employee and top management/ owner level surveys including organizational questions, attitude and emotional surveys) is exceptional.

We have collected all company data (tax number, type of activity, TEAOR number etc), employee data (on the top management and employees who filled out the questionnaire: age, gender, education, family status) and their answers on the specific topic on the flexible employment. Naturally there was not a $100 \%$ response rate, as some data was missing or not filled out properly due to human nature, which will be corrected in the second analysis. There is no comparable analysis in Hungary so far, therefore there is no control group yet, as all the companies who filled out the survey were open to flexible employment.

There is ongoing research in the following correlations:

- Would HR Department (and HR knowledge and support) positively influence the widely spread of flexible forms of employment? 
- What is the relations in between company size (employment number) and flexible employment?

- Which company profile would be more open for flexible employment? (building industry, production industry, infrastructure company, catering industry)

- Is there a difference among different age-groups and their receptiveness on this topic.

I used Hungarian and international studies, literature, the relevant laws, some statistics, and press releases as secondary sources.

\section{REVIEW OF THE RESULTS OF THE MANAGEMENT AND EMPLOYEE SURVEYS SO FAR}

\section{SME managers' answers regarding flexible employment}

Most participating managers were male (66\%). They mostly had higher (57\%) or secondary (40\%) education. Almost a half (43\%) of managers do not have children younger than 18 years of age, while one fifth (20\%) have 1, one quarter (26\%) have 2 children under 18, and less than $10 \%$ have larger families ${ }^{11}$.

Figure 1 Main characteristics of the participating managers

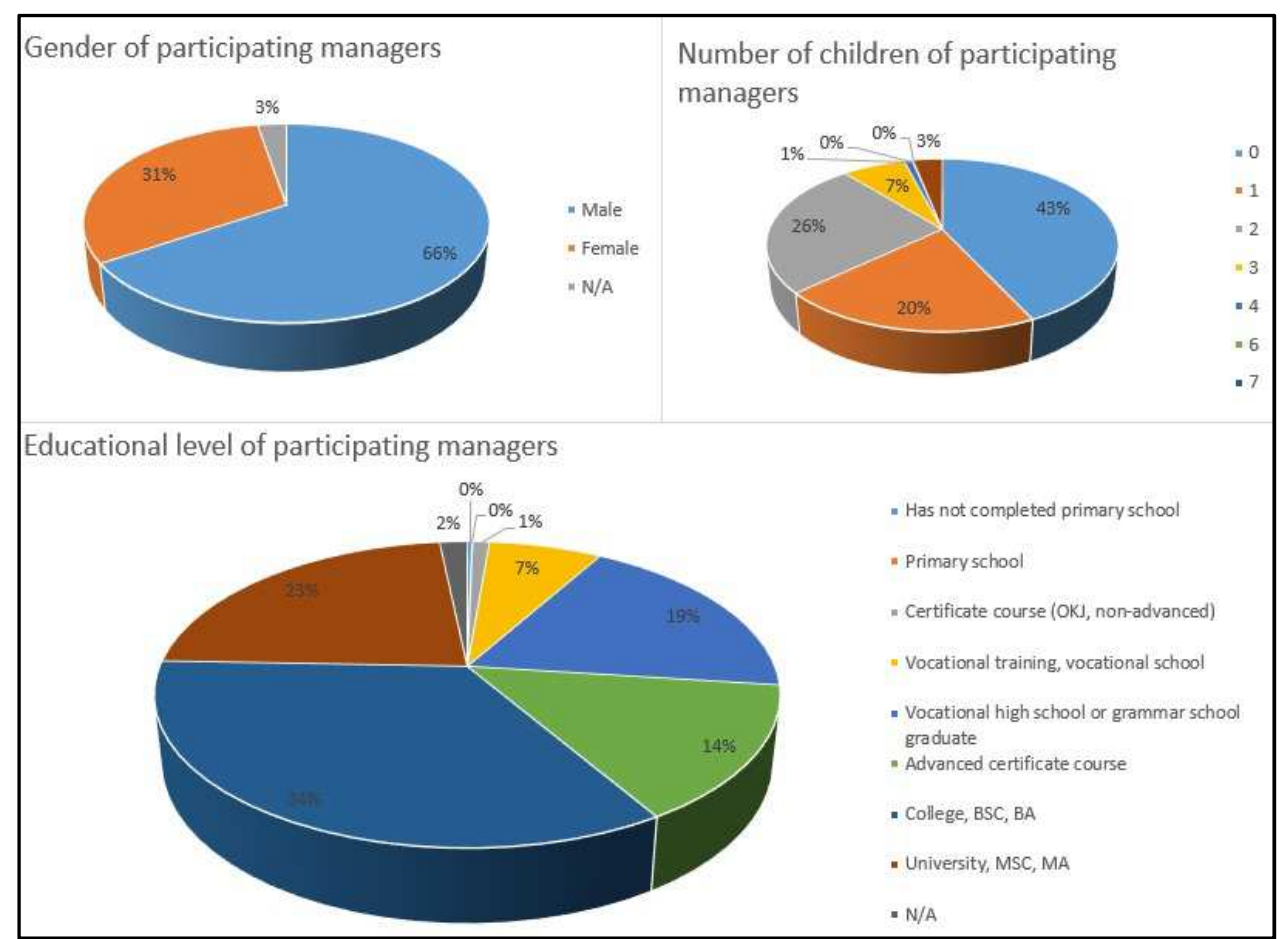

Source: Own elaboration based on data from MAPI co. Ltd.

\footnotetext{
${ }^{11}$ In the survey, the questions asked only related to children under 18 , and during data collection, multiple managers mentioned having grown-up children.
} 
According to the manager questionnaires, part-time (58\%) and weekly/monthly working time (38\%) are the most widespread forms of flexible employment. Other forms (compensatory rest periods, job sharing, daily working time: 5-20\%) and teleworking that is only applicable to few jobs (15\%) are less popular. The main obstacle of their utilisation is not the lack of knowledge, as, other than compensatory rest periods, the majority of forms are known to managers. Based on the answers to questions on implementability, expansion is possible for all atypical forms.

Figure 2 Do the managers utilise the following employment forms?

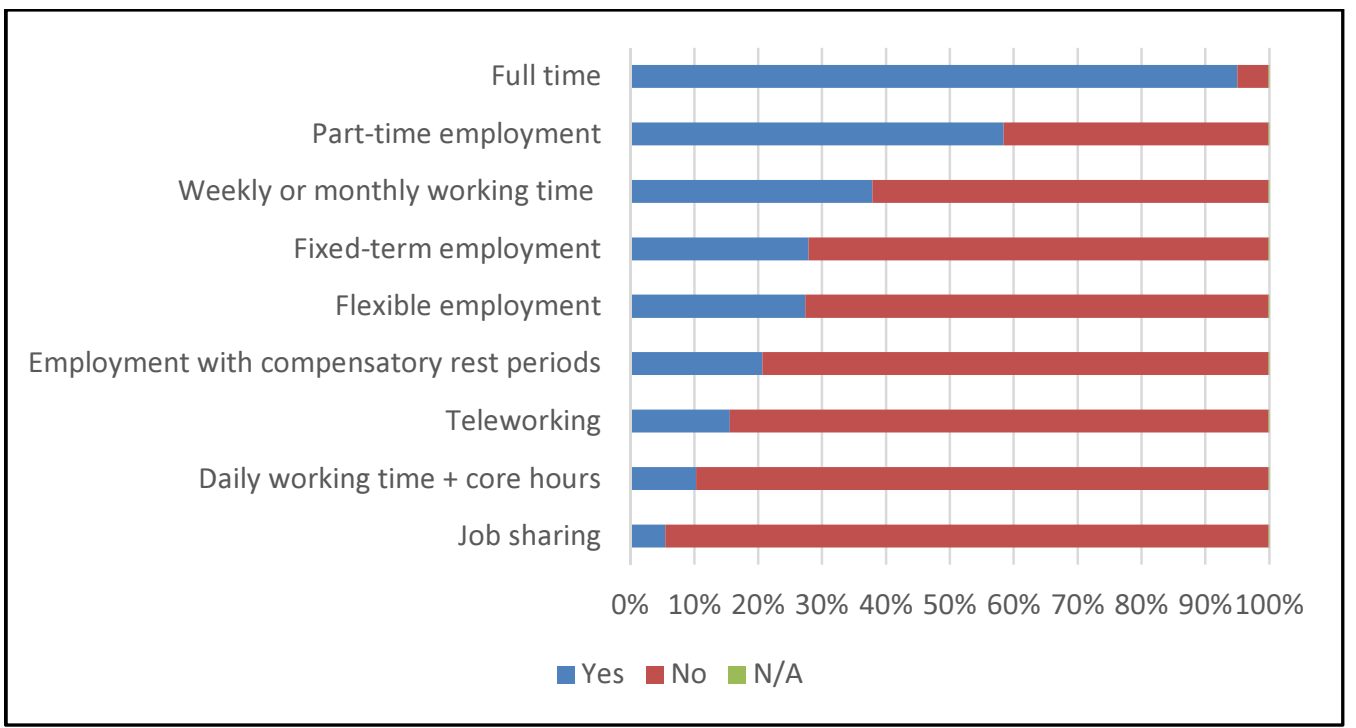

Source: Own elaboration based on data from MAPI co. Ltd.

Figure 3 Do the managers know the following employment forms?

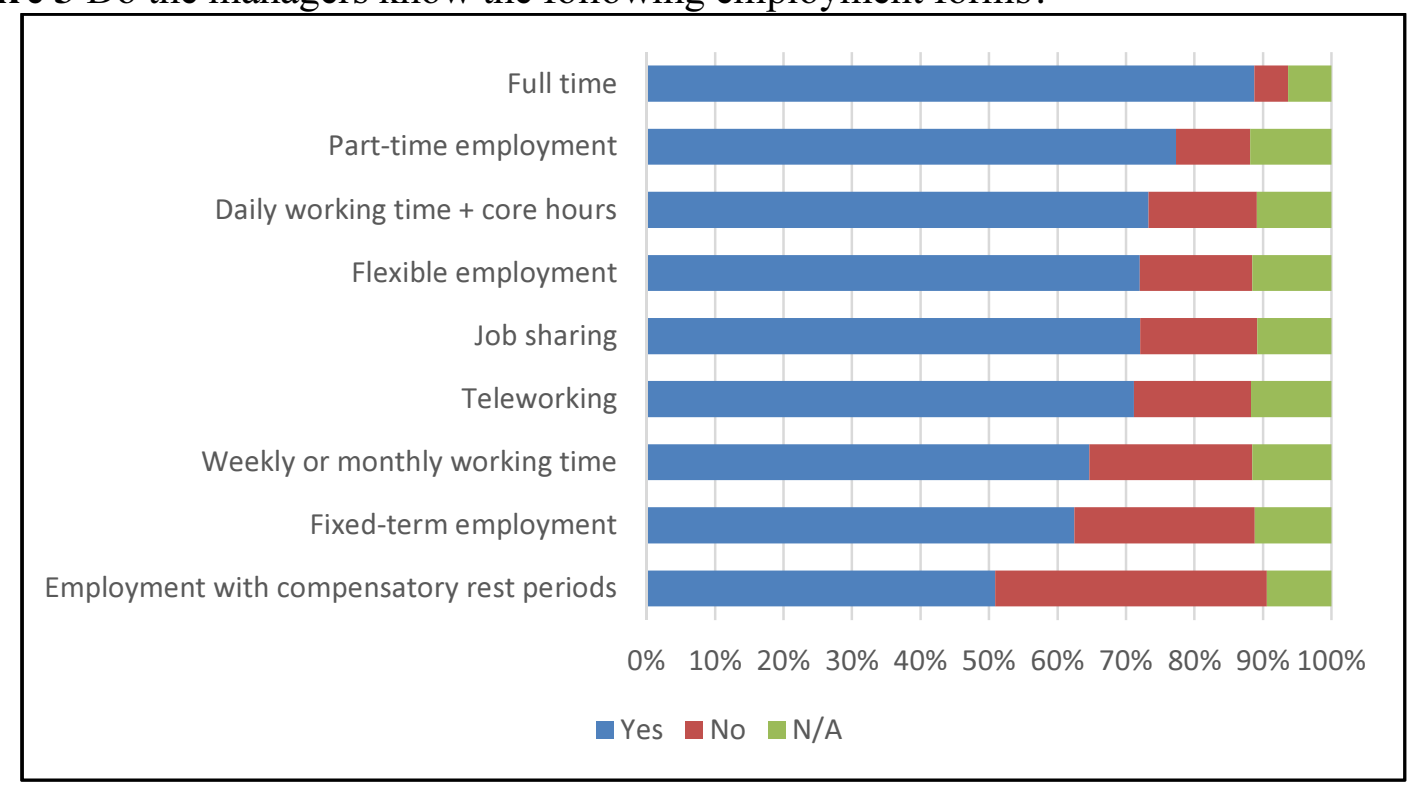

Source: Own elaboration based on data from MAPI co. Ltd. 
Figure 4 Do the managers consider the following flexible

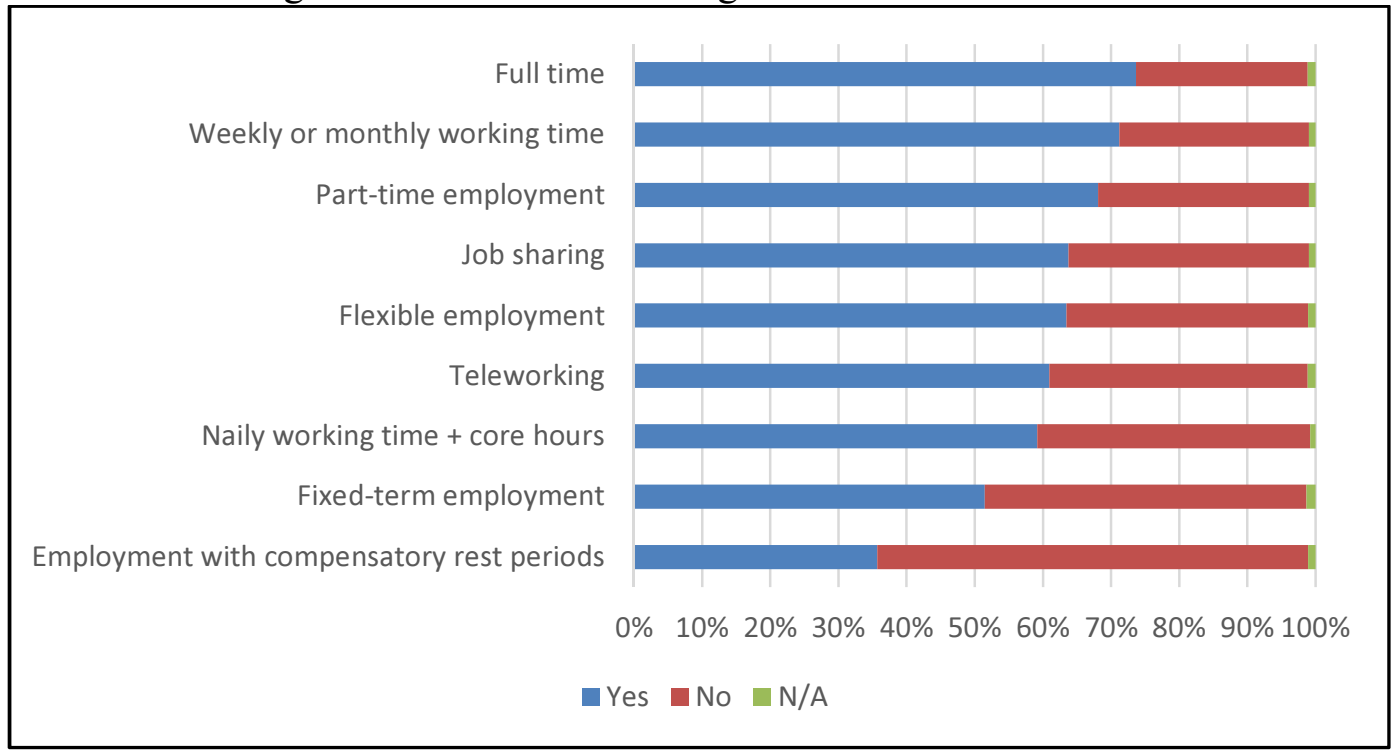

Source: Own elaboration based on data from MAPI co. Ltd.

The managers' attitudes towards flexible employment are, in general, positive. Managers are primarily motivated by financial considerations (better financial results, better customer satisfaction, more efficient operation), but employee-oriented considerations are also significant.

Regarding questions about management fears, managers did not agree with the administration/organisation and cost increasing factors of flexible employment, rather they were worried about releasing control. This is in line with the findings in the literature that deem a conservative managerial attitude that insists on retaining the act of personal handing off of work and control one of the most significant obstacles in this respect.

Figure 5 Managerial attitudes

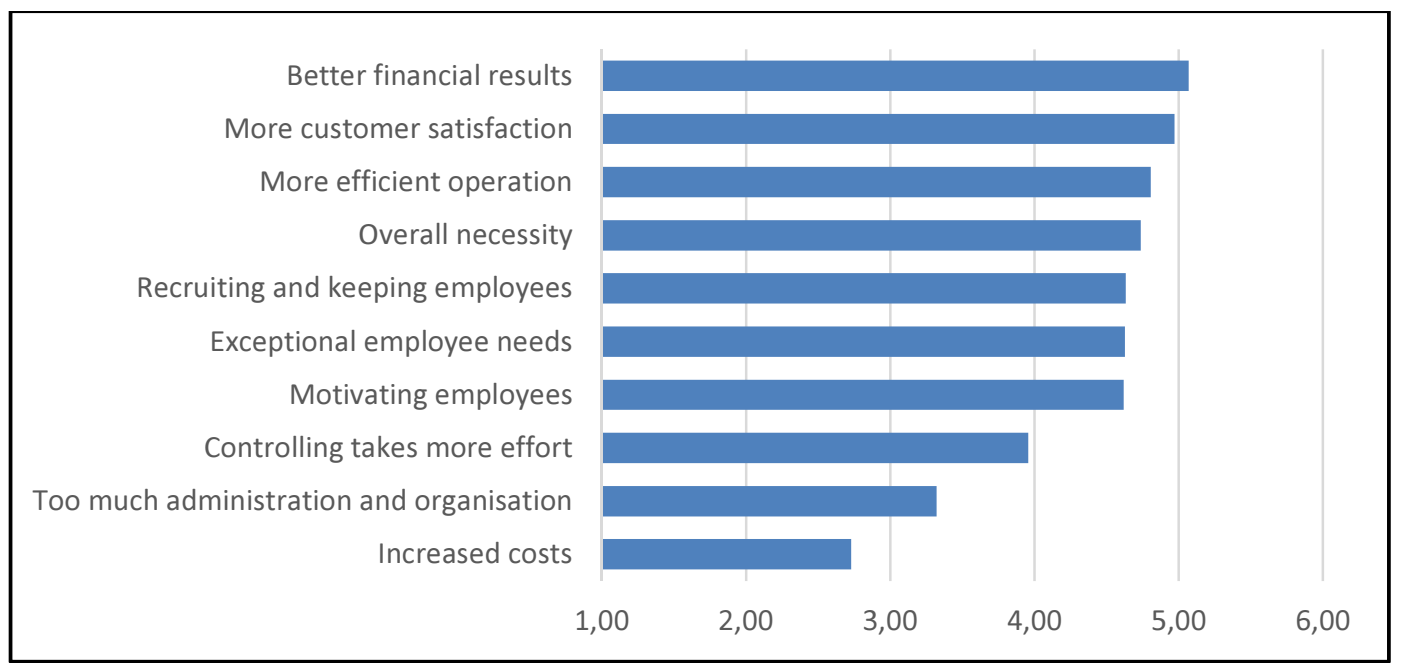

Source: Own elaboration based on data from MAPI co. Ltd. 
It should be underlined that, among the management attitudes regarding employment practices and company culture, on the whole, workplaces are generally considered 'flexible' even today. At the same time, they are sceptical whether this would be a primary selection criterium for employees, and they disagree the most with the idea that communication between employees would decline or this would lead to conflict between employees.

Analysing the answers and the data received, we can clearly state the following hypotheses:

Those companies who have no experience yet on flexible employment, are not fully aware of advantages and disadvantages and they somewhat are sceptical and careful.

Female Leaders are more open to these formats, as well as having more empathy on employment needs.

\section{SME employees' answers regarding flexible employment}

Males were slightly over-represented (51\%) among the participating employees. They mostly had secondary $(36 \%)$ or lower $(43 \%)$ education, unlike managers' $57 \%$, only $18 \%$ had a higher education level in this group. More than half (51\%) of employees did not have children under 18 years of age, about one third (30\%) had 1 or 2 children under 18 , while the ratio of employees with larger families was negligible (6\%).

Figure 6 Main characteristics of participating employees

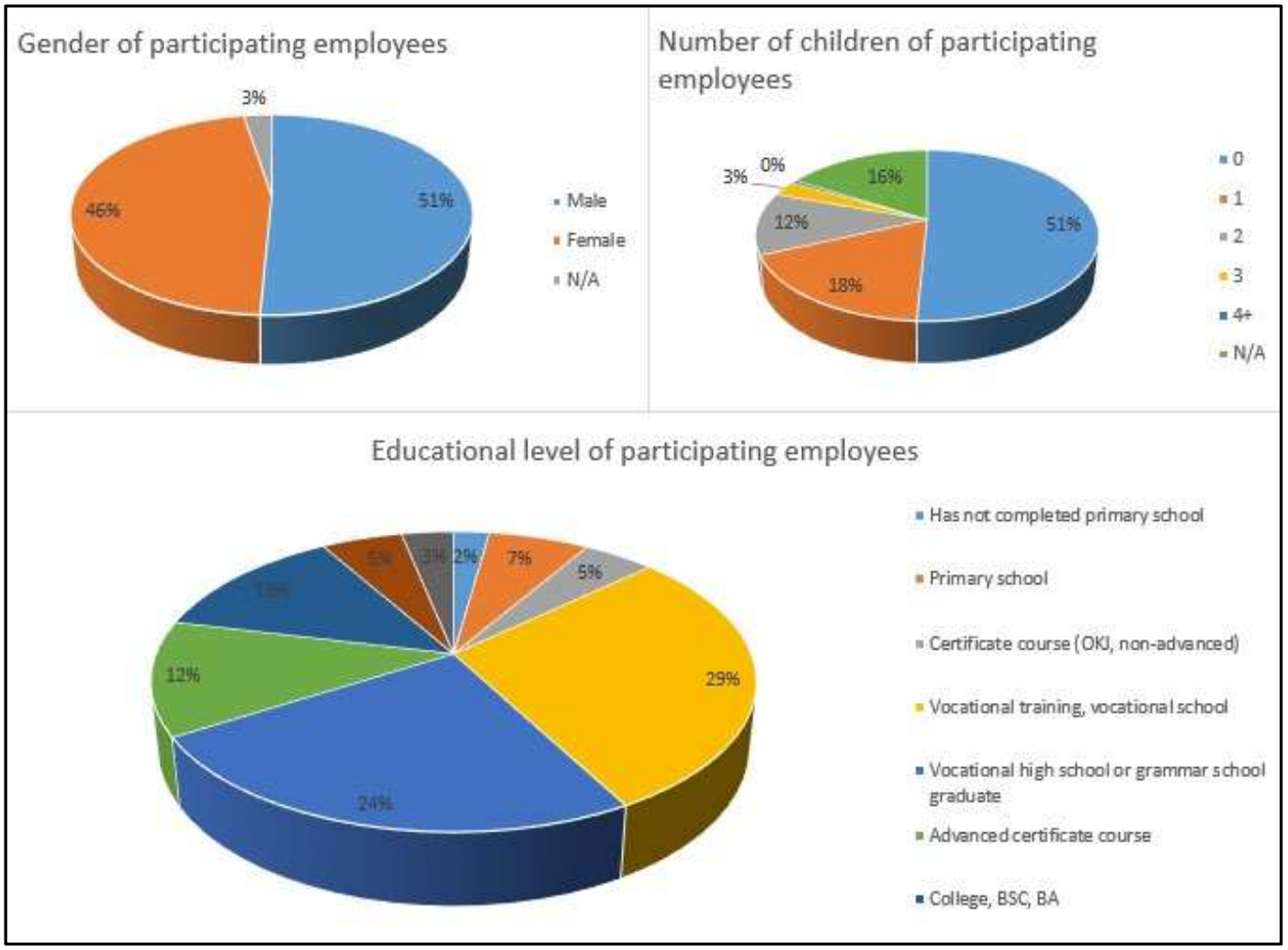

Source: Own elaboration based on data from MAPI co. Ltd. 
According to the employee questionnaires, part-time work (13\%) and utilising weekly/monthly working time (20\%) are the most widespread atypical forms of employment, and $10 \%$ of employees had worked with a fixed-term contract in the past 12 months. Among the other flexible forms, work with compensatory rest periods is the most widespread $(6 \%)$, the other forms requiring special jobs accounted for 2-3\%. Based on whether they found their jobs suitable for atypical work, employees perceived a lot of room for improvement in almost all forms.

Figure 7 What percentage of the surveyed employees have been employed in the following form(s) in the past 12 months?

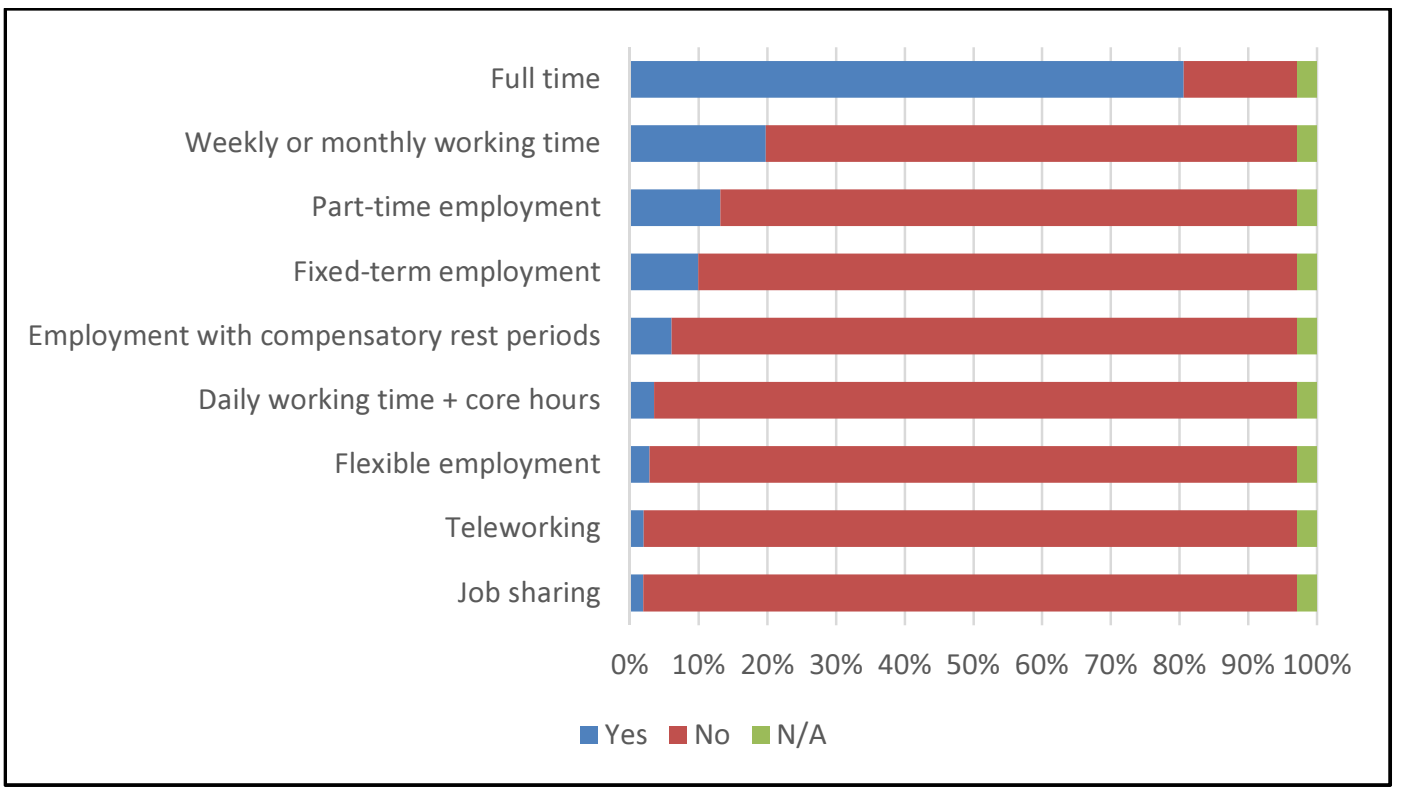

Source: Own elaboration based on data from MAPI co. Ltd.

Figure 8 Do you find your job suitable for the following forms of employment?

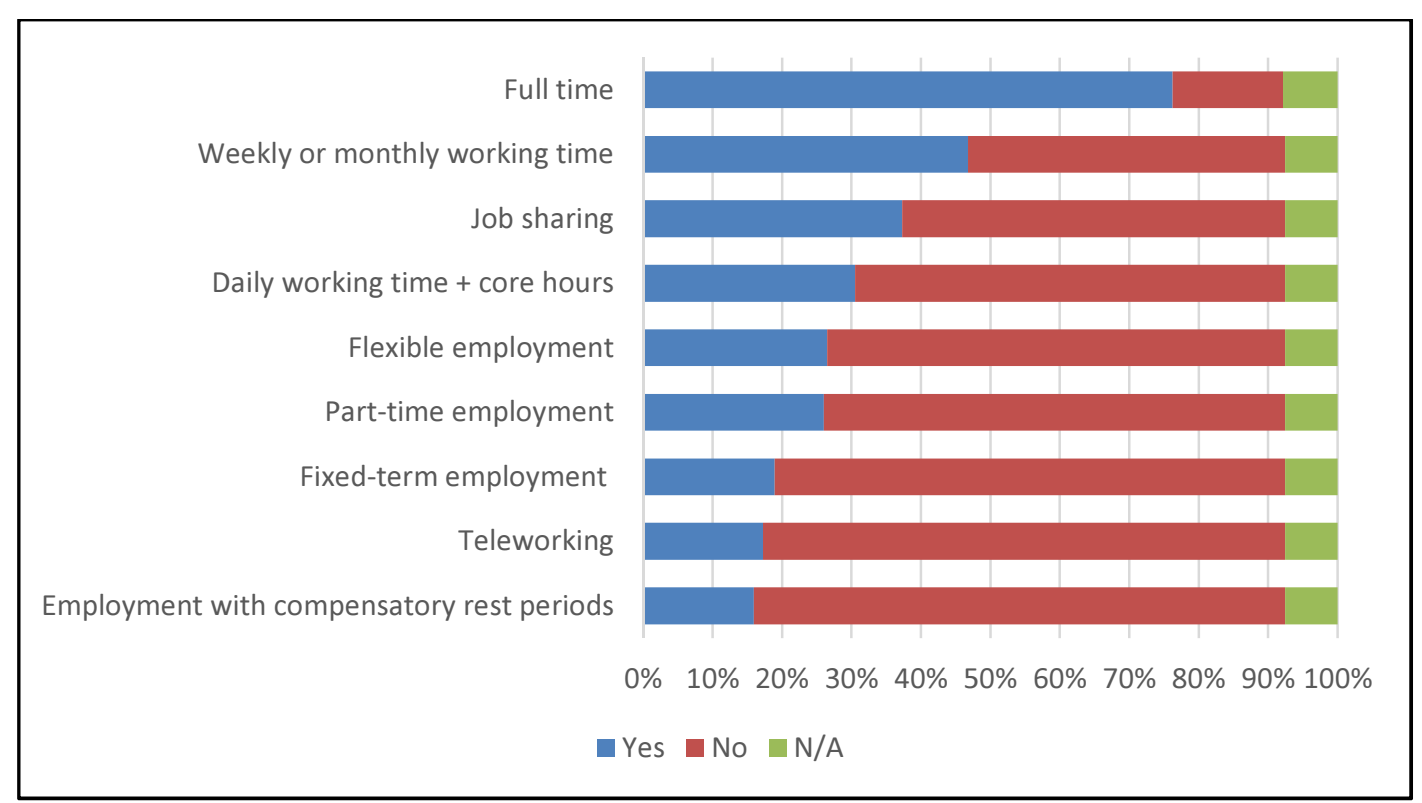

Source: Own elaboration based on data from MAPI co. Ltd. 
As part-time work means a decrease in income, it is not popular among employees regardless of its frequent use as a reaction to individual situations. Employees typically would prefer to work in atypical forms which they associate with more freedom for the employee and a higher level of control over their working time. As the majority of employees are likely to be unaware of the exact content and depth of the various forms (e.g. weekly/monthly working time is the most desired form), they may have inferred the content based on the forms' name, thus making it not worth analysing in depth. The limits of the need for control and freedom are demonstrated by the fact that flexible employment that is suitable for similar associations is somewhat less preferred, and teleworking, along with part-time work, only attracts about one quarter of employees: employees require a clear framework, but expect a logical flexibility in this framework.

Figure 9 Would you like to work in the following forms?

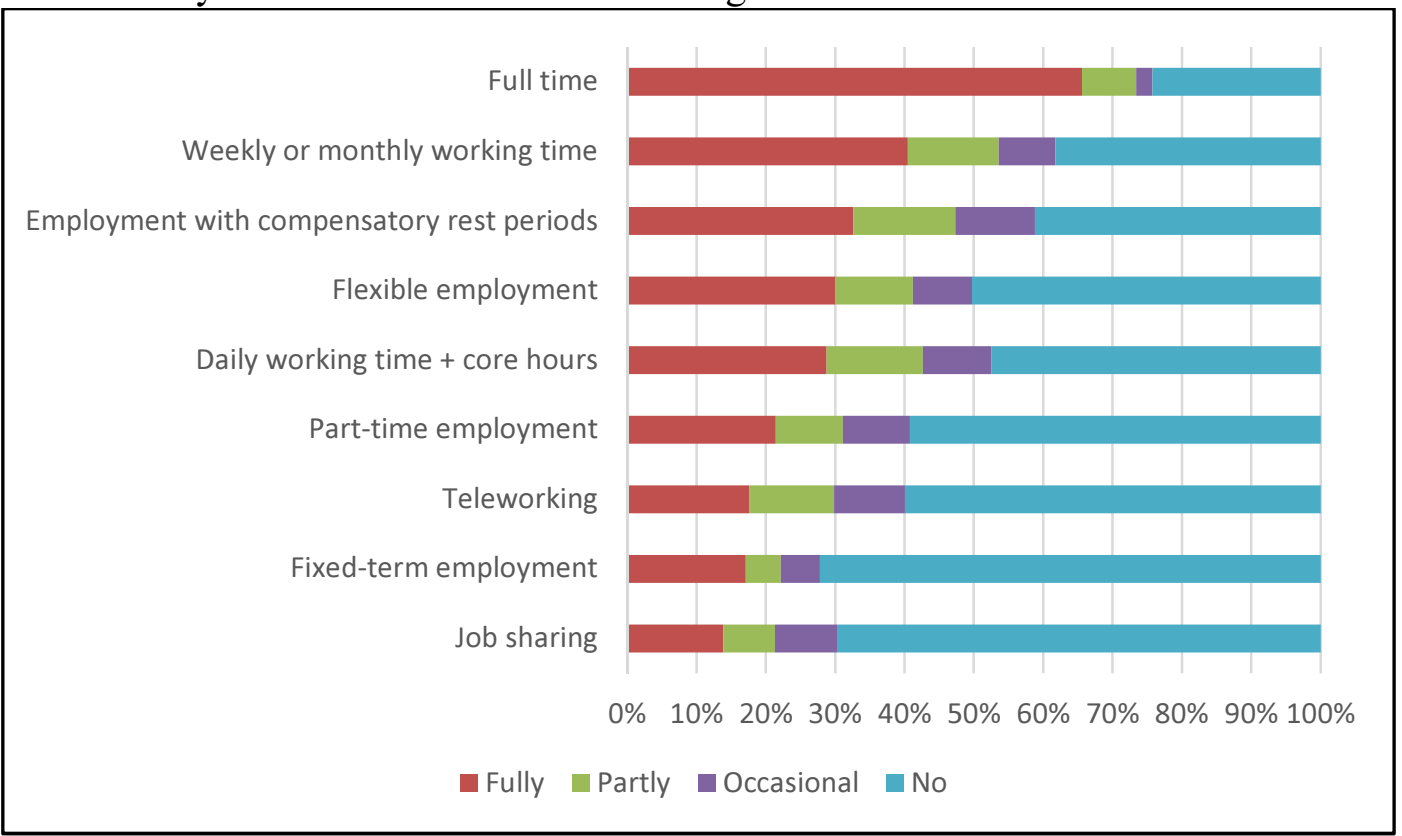

Source: Own elaboration based on data from MAPI co. Ltd.

The employees' answers reinforce the managers' opinion that most participating companies have an open atmosphere and are sensitive to employee problems.

\section{CONCLUSION}

As the development programme supporting the introduction of flexible work is still in progress, I can only publish interim conclusions for the time being (phase 1). In the questionnaire, I surveyed the receptiveness of companies on both the employer and employee sides. The positive attitude towards the issue showed me that participants were interested in 
the topic, therefore I believe that further informing of the participating companies is of primary importance. The survey proved that Hungarian companies are doing better in terms of awareness of flexible forms of employment than in regard to their prevalence. Companies are typically aware of the more general forms of employment, and are only uncertain regarding new and innovative solutions (e.g. job-sharing).

It was also proved that the majority of employees are unlikely to be aware of the exact content and depth of the various forms (e.g. weekly/monthly working time is the most desired form), rather inferring the content based on the forms' name.

The survey proved that employees are rather distrusting of flexible employment. Employees feel the greatest aversion towards fixed-term employment and job sharing, as they probably consider the security of their employment to be at risk.

In most questions, the opinions of managers and employees regarding flexible employment practices are not significantly different. The raw comparison of average employee and average manager opinions reinforces the earlier findings that employees are more open and have a greater need for more control over their working hours (they can imagine scheduling their own work time).

Globalization is a well known expression in the economy, therefore it has a strong effect on the job market including employment forms. Martin and Schumann (1998) were emphasizing that the business world is adjusting to globalization as a tendency." Competition in the brutal global economy will make the job market and employee structure global as well. There is no position which will last forever" - meaning everyone can be replaced.

\section{REFERENCES}

Asztalos, S., Czibere, I., Féki-Kiss, A., Geskó, S., György, A., Gyulavári, T., ...Németh, L. (2011). Exploring and promoting job opportunities suitable for atypical organisation. Final research report. Támop 1.3.1. project 1.3.2. sub-project. Konszenzus Budapest, Budapest.

European Committee (2010). Europe 2020, The strategy of intelligent, sustainable and inclusive growth, Brussels.

Finna, H. (2008). Job market flexibility promoting atypical employment forms at Hungarian SMEs. PhD dissertation Budapest University of Technology and Economics, Faculty of Economic and Social Sciences, PhD School in Business and Management, Budapest.

Frey M. (2001). Status report on the Hungarian state of making working hours systems and employment forms flexible. In: Frey M.: EU-konform foglalkoztatáspolitika (EUconform employment policy), OFA, Budapest.

Frey, M. (2001). Working hours and quality of life. Munkaügyi Szemle, 54(3), 7-9.

Hárs, Á. (2013). Atypical employment: myths, opportunities, and limits of utilising the opportunities of atypical forms of employment. Kopint Konjunktúra Kutatási Alapítvány, Budapest. 
Hovánszki, A. (2005). Typical and atypical employment in Hungary. Munkaügyi Szemle, (49)7-8, pp. 30-36.

Hungarian Ministry of National Economy (2014). Partner Agreement of Hungary for the development period of 2014-2020 by the Hungarian Ministry of National Economy and Office for National economic planning, 15. August, 2014. Budapest.

Köllö, J. (2012). Part-time and other atypical forms of employment. In Fazekas, K. - Scharle, Á. (ed.): Pensions, benefits, public works, OFA, KTI, BI, Budapest. 194-206.

Martin, H. P. \& Schumann, H. (1998). The Global Trap, Globalization and the assault on democracy and prosperity, Perfekt Kiadó, Budapest.

Poór, J. (2014). Typical and atypical employment in Hungarian and Slovak cross-border area in focus Komárno-Komárom and Párkány (Sturovo) and Esztergom (Ostrihom) regions. Selye János University, Szent István University, Komárno, Gödöllő.

Hungarian Central Statistical Office (2015). Employment market status 2014, Hungarian Central Statistical Office, Statisztikai Tükör 2015/45, 24. August 2015.

Szabó, K. \& Négyesi, Á. (2004). Reasons for the increase in atypical work in the knowledge economy. Közgazdasági Szemle, (51)1, pp. 46-65.

Voss, G. (1997). Zur Entwicklung der Arbeitszeiten in der Bundesrepublik Deutschland. In n.d. (Ed.): Mitteilungen des Sonderforschungsbereichs 333 "Entwicklungsperspektven der Arbeit" H.10, pp. 33-58. 